\title{
Immunological evaluation of Lactobacillus casei Zhang: a newly isolated strain from koumiss in Inner Mongolia, China Tuo Ya ${ }^{1,2}$, Qijin Zhang ${ }^{1}$, Fuliang $\mathrm{Chu}^{3}$, Justin Merritt ${ }^{4}$, Menhe Bilige ${ }^{1}$, Tiansong Sun ${ }^{1}$, Ruiting $\mathrm{Du}^{1}$ and Heping Zhang*1
}

Address: ${ }^{1}$ The Key Laboratory of Dairy Biotechnology and Bioengineering, Education Ministry of PR China, Department of Food Science and Engineering, Inner Mongolia Agricultural University, Huhhot 010018, PR China, ${ }^{2}$ Clinical Testing Center, Inner Mongolia Medical College affiliated hospital, Huhhot 010050, PR China, ${ }^{3}$ Institute of Microbiology, Chinese Academy of Sciences, Beijing 100101, PR China and ${ }^{4}$ College of Dentistry, University of Oklahoma Health Sciences Centre, 975 NE 10th St BRC364, Oklahoma City, OK 73104-5419, USA

Email: Tuo Ya - antuoya@163.com; Qijin Zhang - qjzhang@imau.edu.cn; Fuliang Chu - fuliangchu@yahoo.com.cn; Justin Merritt - justinmerritt@ouhsc.edu; Menhe Bilige - mbilige@imau.edu.cn; Tiansong Sun - tssun@imau.edu.cn; Ruiting Du - rtdu@imau.edu.cn; Heping Zhang* - hepingdd@vip.sina.com

* Corresponding author

Published: 19 November 2008

BMC Immunology 2008, 9:68 doi:10.1 186//47|-2172-9-68
Received: 15 July 2008

Accepted: 19 November 2008

This article is available from: http://www.biomedcentral.com/I47I-2172/9/68

(c) 2008 Ya et al; licensee BioMed Central Ltd.

This is an Open Access article distributed under the terms of the Creative Commons Attribution License (http://creativecommons.org/licenses/by/2.0), which permits unrestricted use, distribution, and reproduction in any medium, provided the original work is properly cited.

\begin{abstract}
Background: There is increasing evidence to suggest an immunomodulation function both within the intestines and systemically upon consuming probiotic species. We recently isolated a novel LAB, Lactobacillus caseiZhang (LcZhang) from koumiss. LcZhang exhibited favorable probiotic properties, such as acid resistance, bile resistance, gastrointestinal $(\mathrm{Gl})$ colonization ability, etc. In order to examine the immunomodulatory qualities of LcZhang, we administered LcZhang to healthy mice with varying doses of either live or heat-killed LcZhang and measured various parameters of the host immune response.
\end{abstract}

Results: The study was performed in four separate experiments via oral administration of live and heat-killed LcZhang to BALB/c mice for several consecutive days. We investigated the immunomodulating capacity of LcZhang in vivo by analyzing the profile of cytokines, T cell subpopulations, and immunoglobulin concentrations induced in blood serum and intestinal fluid in $\mathrm{BALB} / \mathrm{c}$ mice. Only live bacteria elicited a wide range of immune responses, which include the increased production of interferon- $\gamma$ (IFN- $\gamma$ ), and depression of tumor necrosis factor- $\alpha$ (TNF- $\alpha$ ) levels. In addition, interleukin-2 (IL-2) and IL-2 receptor gene transcription increased significantly, but the proportion of T cell subsets appeared to be unaffected. We also observed that LcZhang was capable of inducing gut mucosal responses by enhancing the production of secretory Immunoglobulin A (slgA) as well influencing the systemic immunity via the cytokines released to the circulating blood.

Conclusion: The present work shows that the dose-dependent administration of LcZhang is capable of influencing immune responses, implying that it may be a valuable strain for probiotic use in humans. 


\section{Background}

The association between improved health and probiotic bacteria consumption was first documented more than a century ago. Since then, numerous species of bacteria have been examined for their potential health benefits, particularly within the late two decades $[1,2]$. Data from these studies suggest that the effects upon the host might be attributable to the probiotic bacteria themselves through an immunomodulatory activity. These species are able to survive in the human gastrointestinal (GI) tract and influence the host enteric microbiota, which subsequently modulate host immunophysiologic responses. In addition, numerous in vitro, animal model, and human studies also suggest that many of these same species are capable of producing a significant impact upon the host immune system as well [1,2].

As described by Vinderola et al., the two primary routes that probiotic species are able to impact the host are through their direct colonization of the host as well as indirectly by the subsequent release of various metabolites from these species [3]. The former functions via an influence upon the balance of the gut microbial environment. Whereas, the latter route functions through more complex pathways, such as immune recognition of bacterial envelope components, activation of Toll-like receptors, CD14, mannose receptors, etc. [4]. These events have been demonstrated to promote the rapid activation of the NF- $\mathrm{BB}$ and STAT transduction pathways, which subsequently induces the production of pro-inflammatory cytokines [5]. In fact, many characterized probiotic effects are mediated through immune regulation, particularly through perturbations in the balance of pro-inflammatory and anti-inflammatory cytokines [6]. Thus, probiotics can be employed therapeutically to alleviate intestinal inflammation, normalize gut mucosal dysfunction, and downregulate hypersensitivity reactions [6]. Furthermore, this approach also has a robust safety record. Thus, probiotics have many properties that make them highly desirable for the prevention and/or treatment of a wide range of ailments [7].

Previous data has suggested that careful attention should be utilized when selecting strains to be used for probiotic therapy, as differences do exist in the immunomodulatory capacity of bacterial strains. Consequently, we were particularly interested in isolating a probiotic strain with both strong probiotic potential as well as immunomodulatory activity. To this end, we recently isolated a novel LAB, Lactobacillus casei Zhang (LcZhang) from koumiss (a kind of homemade fermented horse milk beverage) widely used in traditional Mongolian medicine in the Inner Mongolia region of China [8-10]. LcZhang exhibited favorable probiotic properties, such as acid resistance, bile resistance, GI colonization ability, etc. [11]. In order to elucidate the immunomodulatory effects of LcZhang, we administered healthy mice with varying doses of either live or heat-killed LcZhang and measured the level of various cytokines, immunoglobulin G (IgG), and T-cell populations in the serum, IL-2 and IL-2 receptor gene expression in the spleen, and secretory immunoglobulin A ( $\operatorname{sg} A)$ in the intestine.

\section{Results \\ Live LcZhang elicits IFN- $\gamma$ production and inhibits TNF- $\alpha$ production in a dose-dependent fashion}

Lcactobacillus Zhang is initially isolated strain from homemade koumiss and determined to be Lactobacillus casei using $16 \mathrm{~S}$ rRNA-based phylogenetic analysis together with a wide array of biochemical assays [8]. In order to examine the immunomodulating capacity of LcZhang, we began by examining its effect upon cytokine levels in the circulating blood of healthy mice. We quantified IFN- $\gamma$ and IL-12 levels in the sera of mice receiving a daily dose of LcZhang for 15 consecutive days. The level of IFN- $\gamma$ increased in all the three dose groups (Fig. 1A). However, only the high dose group elicited a significantly higher response $(\mathrm{P}<0.05)$ compared to the heat killed group and control group (Fig. 1A). IL-12 also increased, but none of groups exhibited a significant difference (Fig. 1B).

As shown in figure $1 \mathrm{C}$, TNF- $\alpha$ production was significantly reduced with a high dose $(\mathrm{P}<0.01)$ and medium dose of LcZhang $(\mathrm{P}<0.05)$. The effect of LcZhang administration on IL-1 $\alpha$ production is shown in figure $1 \mathrm{D}$. No significant changes were observed, though IL- $1 \alpha$ levels were slightly reduced. In addition, the effects were dosedependent. No significant changes were observed to heat killed LcZhang administration (Fig. 1).

\section{IL-2 and IL-2 receptor gene transcription}

In addition to circulating cytokine levels, we were also interested to determine whether LcZhang had the ability to affect cytokine transcription as well. Therefore, IL-2 and IL-2 receptor gene transcription were measured after the intake of LcZhang. As shown in figure 2A, significant increases in IL-2 gene transcription were detected at day 7 and 11 with all dose groups and at day 11, IL-2 mRNA levels peaked at almost double the control. By day 15, both IL-2 and IL-2 receptor gene transcription had decreased with only the high dose samples remaining significantly different from the control (Fig. 2A and 2B). Throughout the assay period, IL-2R gene transcription showed a similar trend with that of IL-2 (Fig. 2B).

\section{T cell subpopulation patterns}

The proportion of CD3+, CD4+, and CD8+ T cells tended to increase slightly over the assay period, but the differences were not significant. Both CD4+, and CD8+ T-cells 



Figure I

Effects of the oral administration of varying doses of LcZhang on cytokines secretion. Induction of major immunoregulatory cytokines (A: IFN- $\gamma$; B: IL- I2; C: TNF- $\alpha$; D: IL-I $\alpha$ ) levels in serum by live LcZhang and heat-killed bacteria after I 5 days oral administration. Data represent the mean \pm standard deviation of each cytokine in $\mathrm{pg} / \mathrm{ml}$ in serum for each test treatment $(n=10)$. Three dosages of bacteria were shown: low dose means $0.25 \times 10^{9} \mathrm{cells} / \mathrm{ml}$; medium dose means $0.5 \times 10^{9}$ cells/ $\mathrm{ml}$; high dose means $1.0 \times 10^{9}$ cells/ml. "Control" refers to the same volume of PBS (open column); "killed" represents heat killed LcZhang (grey column); "live" represents live LcZhang (solid column). Data are means \pm S.D. Error bars represent S.D. $* \mathrm{P}<0.05 ; * * \mathrm{P}<0.01$

and the ratio of CD4+/CD8+ did not seem to be affected by LcZhang (Data not shown).

\section{Intestinal s/gA production}

Intestinal content from the caecum and distal colonic sections were collected from each mouse and the sIgA concentration was measured (Fig. 3A). A significant increase in the concentration of this immunoglobulin was also observed at all dose groups compared to the control. Similar to that of IgG, by the fifth day, sIgA levels peaked and subsequently decreased to a relatively stable level. However, from days 20 - 30, a slight increase in the level of sIgA was observed for each of the dose groups (Fig. 3A). At its peak level on day 5, the high dose group exhibited 4fold increase in sIgA over the control, while medium and low dose groups both showed about a 3-fold increase.

\section{IgG production in serum}

Figure 3B shows significantly increased $\operatorname{IgG}(\mathrm{P}<0.01)$ at every dose group in the serum after ingesting LcZhang. By the fifth day after LcZhang ingestion, IgG levels had also peaked for each dose group with the high dose group exhibiting a 3 -fold increase over the control. This level decreased to about $8 \mathrm{mg} / \mathrm{ml}$ for each dose group after day 10 and remained relatively constant for the remainder of the assay period. Interestingly, the IgG level of the high dose was slightly lower than the medium and low dose groups after the twentieth day (Fig. 3B).

\section{Discussion}

The potential health benefits of consuming lactic acid bacteria ( $\mathrm{LAB}$ ) are increasingly being recognized. In fact, there are some suggestions that LAB commonly used in the dairy industry are therapeutic for diseases such as cancer, various infections, GI disorders, asthma, etc. Because the immune system is an important contributor to each of these diseases, the immunoregulatory effects of LAB were of primary interest. In those studies, cytokine production, antibody (sIgA, IgG, and IgE) production, phagocytic activity, Peyer's patch (PP) activation, T cell function, and 

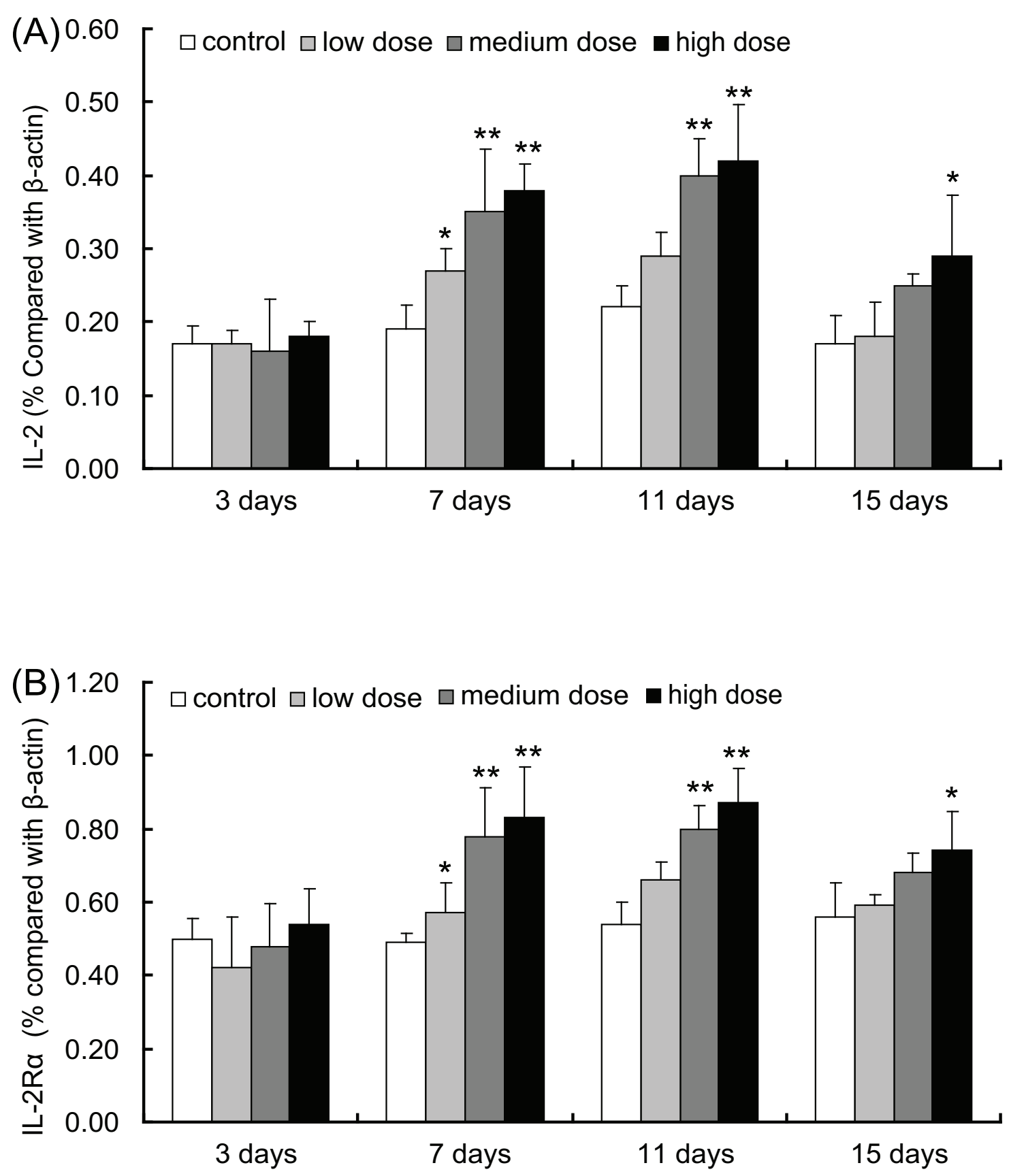

\section{Figure 2}

Analysis of the IL-2 and IL-2R mRNA level in spleen by reverse transcription-PCR. Semi-quantitative detection of IL-2 and IL-2 receptor gene transcription before and after oral administration of live LcZhang with three dosages compared to the gene transcription of $\beta$-actin. A: IL-2 gene transcription; B: IL-2 receptor gene transcription. The relative levels of IL-2 and IL-2R mRNA in mouse spleen was calculated and expressed at the percentage of mRNA to $\beta$-actin. The control (open column) used normal PEF food with $1.0 \mathrm{ml}$ PBS. Three dosages of bacteria were shown: a low dose means $\mathrm{I} \mathrm{ml} \times 0.25 \times 10^{9} \mathrm{cells} / \mathrm{ml}$ (grey column); a medium dose was $\mathrm{I} \mathrm{ml} \times 0.5 \times 10^{9}$ cells $/ \mathrm{ml}$ (dark grey column); a high dose was $\mathrm{I} \mathrm{ml} \times 1.0 \times 10^{9} \mathrm{cells} / \mathrm{ml}(\mathrm{solid}$ column). Data are means \pm S.D. $(n=5)$. Error bars represent S.D. $* \mathrm{P}<0.05 ; * * \mathrm{P}<0.0 \mathrm{I}$. 

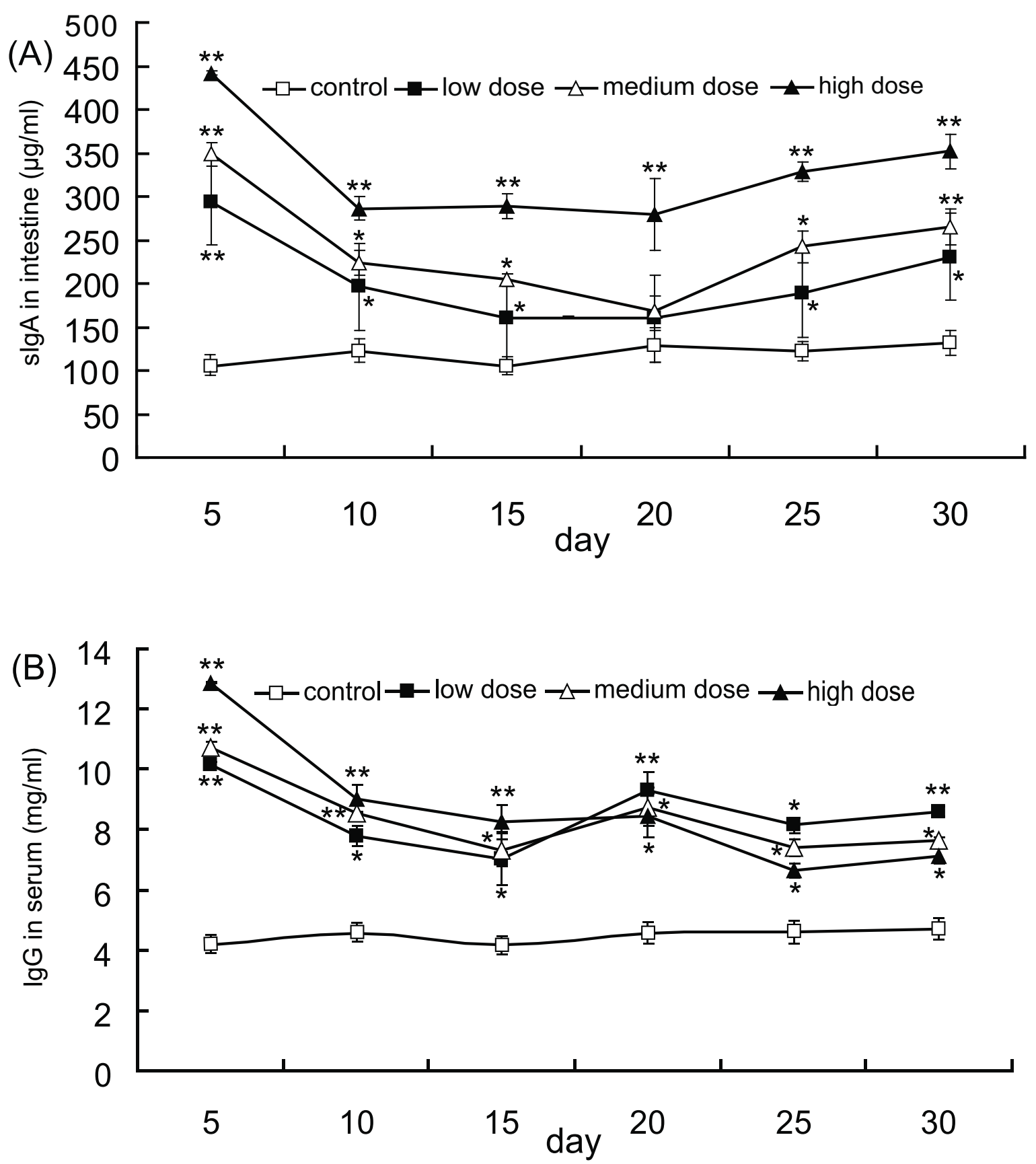

\section{Figure 3}

Time course of the effects of oral administration of varying dosages of LcZhang on immunoglobulin production in serum and in the intestines. ELISA detected slgA level in intestine content and lgG level in serum at every 5 days after oral administration of live LcZhang. A: slgA levels in intestine content; B: IgG levels in serum. Control refers $2.0 \mathrm{ml}$ PBS (open squares); low dose represents $2.0 \mathrm{ml}$ live cells with density of $0.5 \times 10^{9}$ cells $/ \mathrm{ml}$ (solid squares); medium dose represents $2.0 \mathrm{ml}$ live cells with density of $\mathrm{I} \times 10^{9}$ cells $/ \mathrm{ml}$ (open triangles); high dose represents $2.0 \mathrm{ml}$ live cells with density of $2 \times 10^{9}$ cells $/ \mathrm{ml}$ (solid triangles). Five mice were sacrificed in every 5 days. Data are means \pm S.D. $(n=5)$. Error bars represent S.D. *P $<0.05$; **P $<0.01$. 
natural killer (NK) cell activity were shown to increase with $\mathrm{LAB}$ consumption or when cells were exposed to $\mathrm{LAB}$ in vitro or in vivo [6]. It is noted that probiotics interferes basal lymphoproliferation or mitogen-stimulated T- and B-cell proliferation $[12,13]$.

The present study focuses on the immunoregulating capacity of LcZhang, which is a nice probiotic candidate [8]. Our data showed that the pro-inflammatory cytokines IFN- $\gamma$ can be increased in a dose dependent manner after the intake of viable LcZhang. IFN- $\gamma$ is a typical type 1 helper T cell (Th1) cytokine and the augmentation of Th1 cytokines are known to enhance various immune responses. IL-12 stimulates the production of IFN- $\gamma$ and is at least partially associated with the production of Th1 cells. Furthermore, probiotics have been suggested to affect DC maturation and functioning [14]. LABs may potentially influence the development of Th 1 and Th2 via changes in DC types and/or the extent of maturation [15]. Usually, the immunoregulatory effects of probiotics can be ascribed to a skew of the Th1/Th2 balance in favor of Th1 mediated immunity $[4,16,17]$. Consequently, the release of the Th1 associated cytokines IL-12, IFN- $\gamma$ and TNF- $\alpha$ by various cell types has been demonstrated to be increased by LAB [18], which could help to mediate cellular immunity and inhibit the proliferation of Th2 $[19,20]$. Unexpectedly, our results with LcZhang do not completely agree with those reported previously. Specifically, a reduction of TNF- $\alpha$ was observed in the serum. As a proinflammatory cytokine, TNF- $\alpha$ plays a pivotal role in inflammation, mediating fevers, and inducing the liver to produce various detrimental proteins. In certain immune deficiency disorders, elevated TNF- $\alpha$ production has been demonstrated to be a mediator of some of the disease pathology [21]. Thus, LcZhang administration may have some potential utility to help moderate the inflammation associated with elevated TNF- $\alpha$.

Also, via RT-PCR we detected a significant increase of IL-2 and IL-2 receptor gene transcription level after 7 days of oral administration of LcZhang. IL-2 can induce the proliferation of activated T- and B-cells, enhance NK cytotoxicity, and increase the killing activity of monocytes and macrophages for tumour cells and bacteria $[13,20,22]$. Increased IL-2 and IL-2 receptor transcription also implicates the activation of T cells. Collectively, oral administration of LcZhang elicits a modest level of systemic immunoenhancing effects. In this study, the level of sIgA in the intestine was increased by the oral administration of LcZhang. Intestinal secretory IgA plays a principal role in the intestinal immune system: it prevents infection by inhibiting the attachment of bacteria and viruses to the gastrointestinal tract $[23,24]$. Since LcZhang was able to stably increase the level of sIgA for at least 30 days, it is conceivable that LcZhang may have the ability to improve the gastrointestinal mucosal resistance to infections [25]. Indeed, similar results have ever been found with other probiotic strains $[23,24,26]$, but further studies are needed to verify whether this is also the case with LcZhang.

The glycoprotein immunoglobulin G (IgG) accounts for about $75 \%$ of the total immunoglobulins in plasma of healthy individuals. Immunoglobulin G (IgG) antibodies are predominately involved in the secondary antibody response, which occurs later following antigen recognition. The presence of specific IgG generally corresponds to maturation of antibody response. It is interesting that total IgG level in sera increased after administered LcZhang in the present study. With temporal increased IgG level, IgG level restored to normal level after 10 days administration of LcZhang, which is still significantly higher than control group. It is conceivable that some biological activate peptides released from LcZhang may involve in triggering secondary antibodies responses. The mechanism of action is still unknown, further investigation required to evaluate changes of IgG sub-classes, other classes of Ig, such as IgE or IgM, etc.

\section{Conclusion}

In summary, this data indicated that oral administration of LcZhang is able to modulate immune responses. The effects exhibit strong dose-dependent characteristics and is consistently related to the viability of this bacteria. Also, oral administration of LcZhang effected the composition of the intestinal microbiota, which suggests a mechanism by which LcZhang could enhance specifically local as well as systemic immune responses. Further studies are necessary to better assess the full breadth of the immunomodulatory activities of LcZhang. In addition, it is of great interest to measure the effects of koumiss ingestion upon immune system activation in the local population of Inner Mongolia.

\section{Methods}

\section{Bacteria strains and growth condition}

Lactobacillus casei strain Zhang was maintained by subculturing in Trypticase Peptone Yeast broth (TPY; DIFCO, $\mathrm{PQ}$, Canada) using $1 \%$ (vol/vol) inoculums and $24 \mathrm{~h}$ of incubation at $37^{\circ} \mathrm{C}$ and were stored at $4{ }^{\circ} \mathrm{C}$ between transfers. Each culture was subcultured twice in the TPY broth before use [27].

Serial dilutions of freshly-prepared culture were plated onto Man Rogosa Sharpe (MRS) agar/cysteine-HCl and cultured for $36 \mathrm{~h}$ under anaerobic conditions, prior to enumeration. For all experiments involving killed bacterial preparations, samples of freshly-prepared cultures were enumerated using the appropriate agar, while additional samples of the same cultures were heat-killed 
$\left(70^{\circ} \mathrm{C} / 30 \mathrm{~min}\right)$. Subsequently, the concentration of the heat-killed preparation was adjusted in lieu of the live plate counts and used for further experimentation. Successful heat-killing was confirmed by the absence of bacterial growth on appropriate agar plates.

\section{Animal and treatment}

Female Balb/c mice ( 6 weeks of age) with a body weight at about 18-22 g were purchased from the Center for Experimental Animals at the Agriculture University of Inner Mongolia. Guidelines for the care and use of animals were followed and approved by the Ethical Committee of the Agriculture University of Inner Mongolia. Five mice were kept in each cage. Each experimental group consisted of 10 mice in cytokines detection assays, 20 mice in IL-2 gene transcription assay while each experimental group consisted of 30 mice in T cell subpopulation detection and immunoglobulin concentration detection experiments. At each period, 5 mice were sacrificed. The animals were bred specific pathogen free (SPF) and kept in a temperature- and light-controlled environment. The animals were allowed free access to a non-purified MF diet and water until the experiment began. For cytokine measurements and gene transcription experiments, the bacterial suspensions were adjusted with PBS such that a low dose was $0.25 \times 10^{9}$ cells $/ \mathrm{ml}$; medium dose $0.5 \times 10^{9}$ cells/ $\mathrm{ml}$; high dose $1.0 \times 10^{9} \mathrm{cells} / \mathrm{ml}$. Oral gavage volume was $1 \mathrm{ml}$ per day. For assays of $\mathrm{T}$ cell subpopulations and immunoglobulin production, a low dose was adjusted to $0.50 \times 10^{9}$ cells $/ \mathrm{ml}$; a medium dose $1.0 \times 10^{9} \mathrm{cells} / \mathrm{ml}$; and a high dose $2.0 \times 10^{9} \mathrm{cells} / \mathrm{ml}$. Oral gavage volume was 2 $\mathrm{ml}$ per day. Every five days, 5 mice were sacrificed for immunoglobulin production experiments. Sera and intestinal contents were collected immediately.

\section{Detection of cytokine levels in sera}

Blood was collected from the orbital cavity under diethyl ether anesthesia; sera were separated by centrifugation at $1500 \mathrm{rpm}$ for $10 \mathrm{~min}$ at room temperature. Serum was stored at $-70^{\circ} \mathrm{C}$ until further analyzed. The levels of cytokines in sera were determined by capture ELISAs and measured in each case against a standard curve generated by employing known amounts of recombinant cytokine. IFN- $\gamma$, IL-12, TNF- $\alpha$ and IL-1 $\alpha$ were measured using ELISA detection kits (Senxiong Biotech Inc, Shanghai, China) according to the manufacturer's protocol. In all cases, detection antibody binding was visualized using streptavidin-horse radish peroxidase conjugate and an OPD (oPhenylenediamine) substrate system at an OD of $492 \mathrm{~nm}$. For each experiment, the levels of cytokine detected in serum by exposure to LcZhang were determined by comparing against the cytokine levels observed in the standard curves (controls). Data were calculated as the mean cytokine response (in $5 \mathrm{pg} / \mathrm{ml}$ ) of each treatment from triplicate wells, plus or minus the standard deviation.

\section{Analysis of IL-2 and IL-2R gene transcription}

Total RNA was isolated from the spleen with Trizol reagent (Invitrogen, USA) according to the manufacturer's instructions. Initially, a portion of the spleen was frozen in liquid nitrogen, placed in lysis buffer, and immediately disrupted and homogenized using a rotor-stator homogenizer. About 50-100 mg of spleen material was used for RNA isolation with $1 \mathrm{ml}$ of Trizol Reagent. AMV reverse transcriptase (Promega, USA), and oligo-(dT) 15 primers (Promega) were used for generating total cDNA. mRNA levels were also measured by semi-quantitative reverse transcription-PCR. RNA concentration was assessed spectrophotometrically and RNA integrity was visualized with gel electrophoresis. The concentration of all mouse RNA samples was adjusted to $2.5 \mu \mathrm{g} / \mu \mathrm{l}$ by vacuum drying and resuspending in RNase free water (Takara, Japan). All RNA samples were stored at $-80^{\circ} \mathrm{C}$ until used. One step RT-PCR was performed using the commercially available kit (High Fidelity RNA PCR Kit, Takara, Japan). IL-2 and IL-2R gene transcription were evaluated by semi-quantitative RTPCR. The forward primer for IL-2 is 5'-CTGGAGCAGCTGTTGATG-3' and 5'-CGAATTGGCACTCAAATG-3'for the reverse. The size of the amplified IL-2 fragment was 286 base pair (bp). For the IL-2 receptor, the primers are 5'CGGTTTCCGAAGACTAAA-3'and 5'-GTCCTTCCACGAAATGAT-3' for the reverse. The size of the amplified IL$2 \mathrm{R}$ fragment was $266 \mathrm{bp}$. $\beta$-actin gene transcription was used as a housekeeping control for normalization. The $\beta$ actin primer sequences are 5'-GTTACCAACTGGGACGACA-3' and 5'-AGGCATACAGGGACAGCA-3'. The size of the amplified $\beta$-actin fragment was $208 \mathrm{bp}$.

PCR was performed in a reaction volume of $50 \mu \mathrm{l}$, using the High Fidelity RNA PCR Kit (Takara, Japan) according to the instructions of the manufacturer. For PCR, the initial melting temperature was $94^{\circ} \mathrm{C}$ for $4 \mathrm{~min}$, followed by 31 cycles at $94^{\circ} \mathrm{C}$ for $30 \mathrm{~s}, 55^{\circ} \mathrm{C}$ for $30 \mathrm{~s}$ and $72^{\circ} \mathrm{C}$ for 1 min, with a final extension at $72^{\circ} \mathrm{C}$ for $10 \mathrm{~min}$. The PCR products were visualized on a $2 \%$ agarose gel. Amplicon band intensity was calculated using Image Analysis Software (Alpha Innotech Corporation).

\section{Measurement of Immunoglobulin concentration}

Concentration of IgG in sera and sIgA from intestines were determined by ELISA quantitative kits (Sun biomedical Technology Beijng Co., Ltd, Beijing, China) according to manufacturer instructions. Immunoglobulin concentrations were evaluated every five days for a total of 30 days after the oral administration of LcZhang.

\section{Measurement of intestinal slgA}

Immediately after sacrificing the mice, samples from the caecum and distal sections of the intestine from each mouse were collected and homogenized in saline solution (50 mg/ml). Particulate material was removed by centrif- 
ugation at $10,000 \times \mathrm{g}$ for $10 \mathrm{~min}$ at $4{ }^{\circ} \mathrm{C}$. The supernatant fluid was stored at $-80^{\circ} \mathrm{C}$ for IgA measurement. The level of sIgA in supernatants were determined by ELISA quantitation kits (Sun biomedical Technology Co., Ltd, Beijng, China) according to manufacturer instructions.

\section{Measurement of sera IgG}

Blood was collected from the orbital cavity under diethyl ether anesthesia and the sera were separated by centrifugation at $1500 \mathrm{rpm}$ for $10 \mathrm{~min}$ at room temperature. The IgG concentration was determined by ELISA quantitation kits (Sun biomedical Technology Co., Ltd, Beijing, China) according to manufacturer instructions. The IgG level was measured in each case against a standard curve generated by employing known amounts of IgG. The protocols used to quantify IgG are similar to those described for cytokine detection.

\section{Detection of $T$ cell subpopulation}

For immunophenotyping, Peripheral Blood Mononuclear Cells (PBMCs) were washed in PBS supplemented with $0.1 \%$ sodium azide and $1 \%$ normal mouse serum, and incubated for $30 \mathrm{~min}$ at $4{ }^{\circ} \mathrm{C}$ with one of the following monoclonal antibodies (mAbs) (all obtained from BD Pharmingen): fluorescein isothioncyanate (FITC)-conjugated mouse $\mathrm{CD}^{+}{ }^{+}$PE-mouse $\mathrm{CD}^{+}$, and PE-mouse CD8 $\alpha$. Cells were analyzed using a FACSCalibur flow cytometer (Becton Dickinson).

\section{Statistical analysis}

Experimental data was expressed as mean \pm S.D. Statistical analysis (one-way ANOVA) was performed using the GraphPad PRISM version 4.0 (GraphPad Software, San Diego, CA) to analyze the differences among the means of experimental groups. When a parameter of any of the experimental groups was significant, Dunnett's Multiple Comparison Test was used. Differences were considered to be significant at $\mathrm{P}<0.05$ and highly significant at $\mathrm{P}<$ 0.01 .

\section{Abbreviations}

sIgA: secretory immunoglobulin A; IgG: Immunoglobulin G; CFU: colony-forming unit; SPF: specific pathogen free; PBS: phosphate buffered saline; OPD: o-Phenylenediamine; PBMC: Peripheral Blood Mononuclear Cells

\section{Competing interests}

The authors declare that they have no competing interests.

\section{Authors' contributions}

TY, TS and QZ carried out the microbiological work and the animal studies. HZ, BM and TY conceived of the study. TY, QZ, and HZ designed the experiments. FC and TY performed the statistical analyses and prepared the figures. FC and TY wrote the draft of the manuscript. FC, JM and
RD revised it for significant intellectual content. All authors read and approved the final version of the manuscript.

\section{Acknowledgements}

This work was supported by Natural Science Foundation of China (Grant No. 30560097, 30660135 and 30760I56), Hi-tech Research and Development Program of China (863 Program) (Grant No. 2006AA 0Z3345 and 2007AA I 0Z353) and New Century Excellent Talent (NCET) Planning of Education Ministry of China.

\section{References}

I. Cross ML: Microbes versus microbes: immune signals generated by probiotic lactobacilli and their role in protection against microbial pathogens. FEMS Immunol Med Microbiol 2002, 34:245-53.

2. Reid G, Burton J: Use of Lactobacillus to prevent infection by pathogenic bacteria. Microbes Infect 2002, 4:319-24.

3. Vinderola G, Matar C, Palacios J, Perdigon G: Mucosal immunomodulation by the non-bacterial fraction of milk fermented by Lactobacillus helveticus R389. International Journal of Food Microbiology 2007, I I 5: I80-186.

4. Cross ML, Ganner A, Teilab D, Fray LM: Patterns of cytokine induction by gram-positive and gram-negative probiotic bacteria. FEMS Immunol Med Microbiol 2004, 42: I73-80.

5. Miettinen M, Lehtonen A, Julkunen I, Matikainen S: Lactobacilli and Streptococci activate NF-kappa B and STAT signaling pathways in human macrophages. J Immunol 2000, 164:3733-40.

6. Isolauri E, Sutas Y, Kankaanpaa P, Arvilommi H, Salminen S: Probiotics: effects on immunity. Am J Clin Nutr 200I, 73:444S-450S.

7. Mercenier A, Muller-Alouf $\mathrm{H}$, Grangette $\mathrm{C}$ : Lactic acid bacteria as live vaccines. Curr Issues Mol Biol 2000, 2: 17-25.

8. Wang J, Chen X, Liu W, Yang M, Caicike A, Zhang H: Identification of Lactobacillus from koumiss by conventional and molecular methods. Eur Food Res and Technol 2008.

9. Wu R, Zhang $H$, Menghe B: [I6S rDNA sequence and cluster analysis of Lb.casei. Zhang and ZLI2-I isolated from Koumiss]. China Dairy Industry 2005, 33:4-9.

10. Xu ], Yun Y, Zhang W, Shao Y, Menghe B, Zhang H: [Fermentation properties of 4 strains of Lactobacillus casei isolated from traditionally home-made koumiss in inner mongolia of China]. China Dairy Industry 2006, 34:23-27.

II. Zhang H, Menghe B, Wang J, Sun T, Xu J, Wang L, Yun Y, Wu R: [Assessment of potential probiotic properties of L.casei Zhang strain isolated from traditionally home- made Koumiss in Inner Mongolia of China]. China Diary Industry 2006, 34:4-7.

12. Kirjavainen PV, EINezami HS, Salminen SJ, Ahokas JT, Wright PF: Effects of orally administered viable Lactobacillus rhamnosus GG and Propionibacterium freudenreichii subsp. shermanii JS on mouse lymphocyte proliferation. Clin Diagn Lab Immunol 1999, 6:799-802.

13. Kirjavainen PV, El-Nezami HS, Salminen SI, Ahokas JT, Wright PF The effect of orally administered viable probiotic and dairy lactobacilli on mouse lymphocyte proliferation. FEMS Immunol Med Microbiol 1999, 26:131-5.

14. Zeuthen LH, Christensen HR, Frokiaer H: Lactic acid bacteria inducing a weak interleukin- 12 and tumor necrosis factor alpha response in human dendritic cells inhibit strongly stimulating lactic acid bacteria but act synergistically with gramnegative bacteria. Clin Vaccine Immunol 2006, 13:365-75.

15. Stagg AJ, Hart AL, Knight SC, Kamm MA: Microbial-gut interactions in health and disease. Interactions between dendritic cells and bacteria in the regulation of intestinal immunity. Best Pract Res Clin Gastroenterol 2004, I 8:255-70.

16. Mohamadzadeh M, Olson S, Kalina WV, Ruthel G, Demmin GL, Warfield KL, Bavari S, Klaenhammer TR: Lactobacilli activate human dendritic cells that skew $T$ cells toward $T$ helper I polarization. Proc Natl Acad Sci USA 2005, 102:2880-5.

17. Segawa S, Nakakita $Y$, Takata $Y$, Wakita $Y$, Kaneko $T$, Kaneda $H$, Watari J, Yasui H: Effect of oral administration of heat-killed Lactobacillus brevis SBC8803 on total and ovalbumin-spe- 
cific immunoglobulin $E$ production through the improvement of Th I/Th2 balance. Int J Food Microbiol 2008, I 2 I: I- I0.

18. Baken KA, Ezendam J, Gremmer ER, de Klerk A, Pennings JL, Matthee $B$, Peijnenburg AA, van Loveren $\mathrm{H}$ : Evaluation of immunomodulation by Lactobacillus casei Shirota: immune function, autoimmunity and gene expression. Int J Food Microbiol 2006, II 2:8-I8.

19. Nagao F, Nakayama M, Muto T, Okumura K: Effects of a fermented milk drink containing Lactobacillus casei strain Shirota on the immune system in healthy human subjects. Bios $c i$ Biotechnol Biochem 2000, 64:2706-8.

20. Takeda K, Okumura K: Effects of a fermented milk drink containing Lactobacillus casei strain Shirota on the human NKcell activity. J Nutr 2007, I37:79|S-3S.

21. Kaburagi T, Yamano T, Fukushima Y, Yoshino H, Mito N, Sato K: Effect of Lactobacillus johnsonii Lal on immune function and serum albumin in aged and malnourished aged mice. Nutrition 2007, 23:342-50.

22. Targosz M, Labuda A, Czuba P, Biedron R, Strus M, Gamian A, Marcinkiewicz J, Szymonski M: Influence of macrophage activation on their capacity to bind bacterial antigens studied with atomic force microscopy. Nanomedicine 2006, 2:82-8.

23. Fukushima $Y$, Kawata $Y$, Hara $H$, Terada A, Mitsuoka T: Effect of a probiotic formula on intestinal immunoglobulin A production in healthy children. Int J Food Microbiol I 998, 42:39-44.

24. Kaila M, Isolauri E, Soppi E, Virtanen E, Laine S, Arvilommi H: Enhancement of the circulating antibody secreting cell response in human diarrhea by a human Lactobacillus strain. Pediatr Res 1992, 32:|4|-4.

25. Wallace TD, Bradley S, Buckley ND, Green-Johnson JM: Interactions of lactic acid bacteria with human intestinal epithelial cells: effects on cytokine production. J Food Prot 2003, 66:466-72.

26. Perdigon G, Nader de Macias ME, Alvarez S, Oliver G, Pesce de Ruiz Holgado AA: Prevention of gastrointestinal infection using immunobiological methods with milk fermented with Lactobacillus casei and Lactobacillus acidophilus. J Dairy Res 1990, 57:255-64.

27. Sgorbati B, Scardovi V, Leblanc DJ: Plasmids in the genus Bifidobacterium. J Gen Microbiol I982, I 28:2 I2I-3I.
Publish with Bio Med Central and every scientist can read your work free of charge

"BioMed Central will be the most significant development for disseminating the results of biomedical research in our lifetime. "

Sir Paul Nurse, Cancer Research UK

Your research papers will be:

- available free of charge to the entire biomedical community

- peer reviewed and published immediately upon acceptance

- cited in PubMed and archived on PubMed Central

- yours - you keep the copyright 